\title{
Hitung Jumlah Leukosit Pada Penderita Kanker Payudara Pasca Kemoterapi
}

\author{
Suardi $^{1)}$, Nurul Ni'ma Aziz ${ }^{1)}$, Dewi arisanti ${ }^{1)}$, Fatma S. Tondau ${ }^{1)}$ \\ 1) Prodi D3 Teknologi Laboratorium Medis Politeknik Kesehatan Muhammadiyah Makassar \\ Email: suardi1717@gmail.com
}

\begin{abstract}
Abstrak
Kanker payudara atau Carcinoma mammae adalah merupakan masalah utama kesehatan wanita di dunia, karena morbiditas dan mortalitas yang tinggi. Untuk mengurangi morbiditas dan mortalitas yang tinggi diperlukan pengobatan yang tepat salah satunya kemoterapi. Kemoterapi ini bekerja pada sel-sel kanker payudara dan sel-sel yang aktif membelah di karenakan penggunaan obat-obatan yang bersifat sitoksik sehingga kemoterapi sering menimbulkan efek samping seperti mielosupresi. Mielosupresi adalah penurunan sel-sel darah salah satunya leukosit. Leukosit merupakan sistem pertahanan tubuh yang dapat mendeteksi masuknya mikroorganisme serta virus kedalam tubuh. Hal ini akan memperburuk keadaan pasien dan mengancam kelangsungan hidup pasien. Jenis penelitian ini bersifat observasi laboratorik untuk mengetahui jumlah leukosit pada penderita kanker payudara pasca kemoterapi. metode yang digunakan dalam pemeriksaan ini yaitu automatic analyzer dengan menggunakan alat mindray BC-3600 dengan jumlah 5 sampel. Berdasarkan hasil penelitian ini didapatkan bahwa jumlah leukosit pada sampel kanker payudara pasca kemoterapi mengalami laukopenia atau penurunan.
\end{abstract}

Kata kunci: Kanker payudara, Kemoterapi, Leukosit, Mindray BC-3600

\section{PENDAHULUAN}

Kanker menjadi penyebab kematian nomor 2 di dunia sebesar $13 \%$ setelah penyakit kardiovaskuler diperkirakan pada tahun 2030 insiden kanker dapat mencpai 26 juta prang dan 17 juta diantaranya meninggal akibat kanker, terlebih untuk Negara berkembang kejadianya akan lebih cepat. Kanker yang menjadi penyebab kematian setia tahunnya adalah kanker paru, kanker hati, kanker abdomen dan kanker payudara (Siregar \& Nurfitriani, 2019). Kanker payudara adalah kanker kedua terbanyak setelah kanker paru (10,4\% dari seluruh kejadian/ insiden kanker) dan merupakan penyebab kelima kematian akibat kanker di seluruh dunia. Pada tahun 2005 kanker payudara menjadi penyebab kematian 502.000 orang di seluruh dunia.
Kejadian jauh lebih tinggi di Negara Eropa dan Amerika Utara dibandingkan dengan negara berkembang. Di Amerika Serikat (AS), terdapat lebih dari 220.000 kasus baru kanker payudara setiap tahun. Di Indonesia kanker payudara menduduki tempat nomor dua setelah kanker leher rahim dan terbanyak pada usia 45-66 tahun. Kurva kejadian berdasarkan usia bergerak naik terus sejak usia 30 tahun (Syafii, S Aprianti, 2016).

Penatalaksanaan kanker payudara dapat dilakukan dengan cara membedah (operasi), pengobatan kimiawi (kemoterapi), radioterapi dan gabungannya. Kemoterapi, merupakan cara mengobati kanker dengan jalan memberikan zat atau obat yang membunuh sel kanker dan diberikan secara tersebar di seluruh badan 
(sistemik). Pada awal penggunaan kemoterapi, digunakan satu jenis sitostatika tetapi dalam perkembangannya kini umumnya digunakan gabungan sitostatika atau disebut ketentuan pengobatan kimiawi (regimen kemoterapi), dalam upaya untuk mendapatkan khasiat yang lebih ampuh.(Syafii, S Aprianti, 2016).

Efek samping yang dapat terjadi akibat kemoterapi berbasis hormonal mengakibatkan trombositopenia, diare, gangguan pada kelenjar tiroid, dan kemoterapi sitostatika (adriamisin/doksorubisin) menimbulkan mual, muntah, diare, stomatitis, alopesia, rentan terinfeksi, neuropati, myalgia, dan efek samping yang paling sering adalah mielosupresi. Mielosupresi adalah penurunan jumlah hemoglobin, trombosit, neutrophil dan leukosit dari normal, yang menimbulkan anemia, trombositopenia, neutropenia, dan leukositopenia.(Purba, 2015).

Salah satu bagian dari mielosupresi adalah kadar leukosit yang tidak normal. Leukosit (disebut juga sel darah putih) merupakan sel darah yang berperan dalam dalam pertahanan selular dan humoral organisme terhadap zat-zat asing. Hitung sel darah putih (WBC) adalah jumlah total leukosit. Leukosit yang tinggi umumnya berarti tubuh kita sedang melawan infeksi. Leukositosis abnormal dijumpai pada keganasan dan gangguan sumsum tulang tulang tertentu. Leukosit yang rendah artinya ada masalah dengan sumsum tulang. Leukosit yang rendah disebut juga leukopenia atau sitopenia, berarti tubuh kita kurang mampu melawan infeksi (Utara et al., 2018).

Dari latar belakang di atas, peneliti ingin mengetahui jumlah leukosit pada penderita kanker payudara pasca kemoterapi yang akan diperiksa di Laboratorium Patologi Klinik Rumah Sakit Dr. Wahidin Sudirohusodo Makassar.

\section{METODE PENELITIAN}

Jenis penelitian dalam metode ini adalah bersifat observasi laboratorik yaitu menghitung jumlah leukosit pada penderita kanker payudara pasca kemoterapi. Teknik pengambilan sampel dilakukan secara purposive sampling dengan populasi dalam penelitian ini adalah pasien penderita kanker payudara dan jumlah sampel pada penelitian ini adalah darah dengan banyak 5 sampel pasien penderita kanker payudara. Data diolah secara deskriptif ditabulasi dan disajikan dalam bentuk table presentasi masing-masing jumlah yang diperoleh. Lokasi pengambilan sampel di Rumah Sakit Umum Wisata Universitas Indonesia Timur Makassar dan lokasi penelitian di laboratorium Patologi Klinik Rumah Sakit Umum Wisata Universitas Indonesia Timur.

\section{Alat dan Bahan}

Alat yang digunakan adalah Midrey BC-3600, tabung EDTA, Torniquet, Spoit, Hanscoon, Masker dan Bahan yang digunakan adalah Darah.

\section{Prosedur Penelitian}

Penelitian ini diawali dengan pengambilan darah minimal $500 \mu \mathrm{L}$ kemudian cek alat dalam keadaan ready, klik manual ID lalu masukkan RM, nama pasien, umur, jenis kelamin kemudian pilih pemeriksaan mode whole blood/capillary klik ok. Masukkan sampel yang sudah homogeny pada aspiration part 
kemudian tekan start dan tunggu sampai probe naik ke atas. Tunggu hasil keluar pada layar monitor (klik explorer pada tool bar) kemudian lihat hasil.

\section{HASIL DAN PEMBAHASAN}

Hasil penelitian yang dilaksanakan di laboratorium RS Umum Wisata Universitas Indonesia Timur mengenai hitung jumlah leukosit pada penderita kanker payudara pasca kemoterapi dengan jumlah sampel darah sebanyak 5 sampel menggunakan metiode automatic analyzer alat mindray BC-3600. Dari hasil pemeriksaan, didapatkan penurunan kadar leukosit pada ke 5 sampel tersebut. hasilnya ditunjukkan pada tabel

1.

Tabel 1. Hasil Pemeriksaan Leukosit pada Penderita Kanker Payudara Pasca Kemoterapi

\begin{tabular}{ccccc}
\hline $\begin{array}{c}\text { Kode } \\
\text { Sampel }\end{array}$ & $\begin{array}{c}\text { Umur } \\
\text { (th) }\end{array}$ & $\begin{array}{c}\text { Jenis } \\
\text { Kelamin }\end{array}$ & $\begin{array}{c}\text { Hasil Jumlah } \\
\left.\text { Leukosit (sel/mm } \mathbf{m m}^{\mathbf{3}}\right)\end{array}$ & $\begin{array}{c}\text { Nilai } \\
\text { Rujukan } \\
\left(\mathbf{s e l} / \mathbf{m m}^{3}\right)\end{array}$ \\
\hline $\mathrm{A}$ & 50 & $\mathrm{P}$ & 2,0 & $4,0-12,0$ \\
$\mathrm{~B}$ & 48 & $\mathrm{P}$ & 3,1 & $4,0-12,0$ \\
$\mathrm{C}$ & 52 & $\mathrm{P}$ & 1,2 & $4,0-12,0$ \\
$\mathrm{D}$ & 46 & $\mathrm{P}$ & 3,9 & $4,0-12,0$ \\
$\mathrm{E}$ & 57 & $\mathrm{P}$ & 2,5 & $4,0-12,0$ \\
\hline
\end{tabular}

Berdasarkan tabel 1 didapatkan paling banyak mengalami kerusakan adalah penurunan jumlah sel leukosit yaitu pada sampel A 2,0 $0 \mathrm{sel} / \mathrm{mm}^{3}$, sampel B 3,1 $\mathrm{sel} / \mathrm{mm}^{3}$, sampel C $1,2 \mathrm{sel} / \mathrm{mm}^{3}$, sampel D $3,9 \mathrm{sel} / \mathrm{mm}^{3}$ dan sampel E 2,5 $\mathrm{sel} / \mathrm{mm}^{3}$ Dari ke 5 sampel menunjukkan terjasinya penurunan jumlah sel leukosit (leukopenia). Pengambilan sampel darah dari penderita kanker payudara yang menjalani kemoterapi.

Pengobatan yang umum diberikan pada pasien kanker payudara adalah keoterapi Obat-obat kemoterapi biasanya diberikan dalam bentuk injeksi maupun pil. obat-obatan kemoterapi terutama bekerja pada DNA yang merupakan komponen utama gen yang mengatur pertumbuhan dan diferensiasi sel. Kemoterapi bekerja dengan menghambat sintesis DNA dan RNA, juga merusak replikasi DNA, mengganggu transkripsi DNA oleh RNA, serta mengganggu kerja gen dan pembentukan protein.

Obat kemoterapi tidak hanya membunuh sel kanker, namun dapat menyerang sel-sel sehat. Jaringan yang organ yang mempunyai daya proliferasi tinggi, seperti sumsum tulang. Supresi sumsum tulang yang biasa terjadi merupakan efek samping kemoterapi salah satunya penurunan sel darah putih (leukopenia).

\section{KESIMPULAN}

Berdasarkan hasil penelitian yang telah dilakukan, dapat disimpulkan bahwa hitung jumlah leukosit pada penderita kanker payudara pasca kemoterapi di RS Umum Wisata Universitas Indonesia Timur sebanyak 5 sampel darah penderita kanker payudara bahwa jumlah leukositnya mengalami leukopenia atau penurunan.

\section{DAFTAR PUSTAKA}

Purba, rimbun anita rosmani. (2015). Hubungan Jenis Kemoterapi Dengan Mielosupresi Pada Kanker Payudara Di Rumah Sakit Umum Pusat Haji Adam Malik Medan. 1-12.

Siregar, D. H., \& Nurfitriani, N. (2019). Hubungan Dukungan Keluarga dengan Kejadian Depresi pada Pasien Kanker Payudara di Rumah Sakit 
Umum Daerah Raden Mattaher Jambi. Jurnal Akademika Baiturrahim Jambi, $8(2)$, $42-50$. https://doi.org/10.36565/jabj.v8i2.12

Syafii, S Aprianti, H. (2016). CLINICAL PATHOLOGY AND Majalah Patologi Klinik Indonesia dan Laboratorium Medik CLINICAL PATHOLOGY AND Majalah Patologi Klinik Indonesia dan Laboratorium Medik. 2 Indonesian
Journal of Clinical Pathology and Medical Laboratory, 14(2). https://doi.org/10.24293/ijcpml.v18i2. 1003

Utara, U. S., Utara, U. S., \& Utara, U. S. (2018). Hubungan Jumlah Leukosit dengan Gambaran Kelainan Kulit pada Pasien Leukemia Limfositik Akut ( LLA ) dan Leukemia Mielositik Akut ( LMA ) Anak di RSUP Haji Adam Malik Medan. 